\title{
BRAZILIAN KEFIR: STRUCTURE, MICROBIAL COMMUNITIES AND CHEMICAL COMPOSITION
}

\section{Karina Teixeira Magalhães ${ }^{1}$, Gilberto Vinícius de Melo Pereira ${ }^{1}$, Cássia Roberta Campos ${ }^{1}$, Giuliano Dragone ${ }^{2}$, Rosane Freitas Schwan $^{1^{*}}$}

\author{
${ }^{1}$ Departamento de Biologia, Universidade Federal de Lavras, Lavras, MG, Brasil; ${ }^{2}$ Institute for Biotechnology and Bioengineering, \\ Centre of Biological Engineering, University of Minho, Campus de Gualtar, 4710-057, Braga, Portugal.
}

Submitted: October 30, 2009; Approved: January 13, 2011.

\begin{abstract}
Microbial ecology and chemical composition of Brazilian kefir beverage was performed. The microorganisms associated with Brazilian kefir were investigated using a combination of phenotypic and genotypic methods. A total of 359 microbial isolates were identified. Lactic acid bacteria (60.5\%) were the major isolated group identified, followed by yeasts (30.6\%) and acetic acid bacteria (8.9\%). Lactobacillus paracasei (89 isolates), Lactobacillus parabuchneri (41 isolates), Lactobacillus casei (32 isolates), Lactobacillus kefiri (31 isolates), Lactococcus lactis (24 isolates), Acetobacter lovaniensis (32 isolates), Kluyveromyces lactis (31 isolates), Kazachstania aerobia (23 isolates), Saccharomyces cerevisiae (41 isolates) and Lachancea meyersii (15 isolates) were the microbial species isolated. Scanning electron microscopy showed that the microbiota was dominated by bacilli (short and curved long) cells growing in close association with lemon-shaped yeasts cells. During the $24 \mathrm{~h}$ of fermentation, the protein content increased, while lactose and fat content decreased. The concentration of lactic acid ranged from 1.4 to 17.4 $\mathrm{mg} / \mathrm{ml}$, and that of acetic acid increased from 2.1 to $2.73 \mathrm{mg} / \mathrm{ml}$. The production of ethanol was limited, reaching a final mean value of $0.5 \mathrm{mg} / \mathrm{ml}$.
\end{abstract}

Key words: Lactobacillus; Saccharomyces; fermented beverage; Brazilian kefir grains

\section{INTRODUCTION}

Kefir is a known culture employed to produce the traditional Russian beverage "kefir" from milk, which has low alcohol content $(8,13)$. It is a mixed culture of various yeast species of the genera Kluyveromyces, Candida, Saccharomyces and various lactic acid bacteria of the genus Lactobacillus, are contained in a matrix of proteins and polysaccharide 'kefiran', which are formed during cell growth under aerobic conditions
(6, 19, 24). Kefir grains are small irregularly shaped, yellowish-white, hard granules which resemble miniature cauliflower blossoms (10).

The beverage is a self-carbonated that owes its distinctive flavor to a mixture of lactic acid, ethanol, carbon dioxide and other flavor products, such as acetaldehyde. The unique flavor is the result of the symbiotic metabolic activity of a number of lactic bacteria and yeast species $(9,13)$. The typical yoghurt flavor kefir is caused by lactic bacteria that produce lactic acid, 
which imparts an acidic and refreshing taste, and the mixture of various carbonyl compounds like acetone, diacetyl, and acetaldehyde of which the latter is considered the major flavour component $(5,20)$.

Kefir grains are added to different types of milk. It can be made from any type of milk; cow, goat or sheep, coconut, rice and soy but commonly cow milk is used. The grains cause its fermentation that results in the production of numerous components in the kefir, including lactic acid, acetic acid, $\mathrm{CO}_{2}$, alcohol (ethyl 2 alcohol) and aromatic compounds. That provides kefir's unique sensory characteristics: fizzy, acid taste, tart and refreshing flavor $(9,22)$. The beverage contains vitamins, minerals and essential amino acids that help the body with healing and maintenance functions and also contains easily digestible complete proteins $(9,13,22)$. The benefits of consuming kefir in the diet are numerous (19): antitumor activity (28), antimicrobial activity (25), antiinflammatory, and antiallergic activity (15).

In Brazil, kefir grains are used in private household for fermentation of milk and while microbial and chemical information is available concerning Irish (23), Turkish $(10,31)$, and Spanish kefir grains (13), there are no reports concerning the microbial or chemical characterization of Brazilian kefir. Therefore, the aim of this study was to assess the microbial diversity of Brazilian kefir beverage. For this purpose, a combined approach of phenotypic and genotypic identification using sequencing of portions of the $16 \mathrm{~S}$ rRNA gene and Iternal Tanscribed Spacer region (ITS) was performed. Also, physicochemical and Scanning Electron Microscopy (SEM) characterizations were used for the beverage and kefir grains respectively. The microbial and chemical composition of Brazilian kefir beverage is one of the prerequisites for the successful future implementation of industrial-scale production.

\section{MATERIALS AND METHODS}

\section{Milk Brazilian kefir production}

Brazilian kefir grains were obtained from a private household in the city of Lavras, which is located in the southern State of Minas Gerais, Brazil. The grains (250 g) were washed with distilled water and inoculated in $2.250 \mathrm{ml}$ of substrate (Pasteurized whole milk, Ipê - Cooperativa Agrícola Alto Rio Grande Ltda. Lavras, Minas Gerais, Brazil) and were statically incubated for $24 \mathrm{~h}$ at $25^{\circ} \mathrm{C}$. Samples of the beverage were aseptically taken every $6 \mathrm{~h}$. Four fermentations were performed in the same conditions described above.

\section{Enumeration of mesophilic bacteria, acetic acid bacteria, lactic acid bacteria and yeasts}

Bacteria and yeasts were enumerated by the surface spread technique, plating in triplicate $100 \mu \mathrm{l}$ of each diluted sample. Enumeration of microorganisms was carried out using 7 different culture media. Lactic acid bacteria's (LAB) were enumerated on Nutrient Agar medium (Oxoid, S/P, Brazil), De Man, Rogosa and Sharpe Agar (MRS) (Oxoid, S/P, Brazil), M17 agar (Oxoid, S/P, Brazil), Edwards modified medium (Oxoid, S/P, Brazil) and LUSM medium (1.0\% glucose, $1.0 \%$ Bacto Peptone (Difco, S/P, Brazil), 0.5\% yeast extract (Difco, $\mathrm{S} / \mathrm{P}$, Brazil), $0.5 \%$ meat extract (Difco, S/P, Brazil), $0.25 \%$ gelatin (Difco, S/P, Brazil), $0.5 \%$ calcium lactate, $0.05 \%$ sorbic acid, 75 ppm of sodium azide (Sigma, St. Louis, USA), $0.25 \%$ sodium acetate, $0.1 \%(\mathrm{vol} / \mathrm{vol})$ Tween $80,15 \%$ tomato juice, 30 micrograms of vancomycin (Sigma, St. Louis, USA) per ml, 0.20 microgram of tetracycline (Sigma, St. Louis, USA) per $\mathrm{ml}, 0.5 \mathrm{mg}$ of cysteine hydrochloride per $\mathrm{ml}$, and $1.5 \%$ agar (Difco, S/P, Brazil). Acetic acid bacteria's (AAB) were enumerated on 135 medium (DSMZ, Deutsche Sammlung von Mikroorganismen und Zellkulturen GmbH, Germany). All media for bacterial enumeration were supplemented with 0.4 $\mathrm{mg} / \mathrm{ml}$ nystatin (Sigma, St. Louis, USA). Yeasts were enumerated on YEPG agar containing $100 \mathrm{mg}$ chloramphenicol (Sigma, St. Louis, USA) and $50 \mathrm{mg}$ chlortetracycline (Sigma, St. Louis, USA) to inhibit bacterial growth. After spreading, plates were incubated at $28^{\circ} \mathrm{C}$ for $48 \mathrm{~h}$ for bacteria, and 5 days for yeasts; and colony forming units $\left(\log _{10}\right.$ c.f.u./ml) were quantified. For each type of medium containing isolated 
colonies, the square root of the number of colonies was taken at random for identification (12).

\section{Phenotypic identification of microorganisms}

Bacterial isolates were Gram-stained. Gram-negative bacteria were identified using Bac-Tray Kits I, II and III (Difco, S/P, Brazil) according to the manufacturer instructions. Gram-positive bacteria were subdivided into sporeformers and non-spore-formers by heating at $80^{\circ} \mathrm{C}$ for $10 \mathrm{~min}$ to kill the vegetative cells. Subsequent identification was performed using biochemical and motility tests as recommended in Bergey's Manual of Determinative Bacteriology (12) and The Prokaryotes (11), and results were confirmed by using the API $50 \mathrm{CHB}$ galleries (Bio-Merieux, S/P, Brazil). Isolates were examined for colony and cell appearance, catalase activity, Gram staining, motility and production of $\mathrm{CO}_{2}$ from glucose in MRS broth with a Durham tube. Biochemical characterizations of the strains were performed with API ID 32 for Lactococcus and Enterococcus and API 50 CHL (BioMerieux, S/P, Brazil) for Lactobacillus and Leuconostoc. All Lactobacillus were recognized as catalase-negative, oxidase-negative, regular fermentative rods. They were classified into obligately homofermentative, facultatively heterofermentative and obligately heterofermentative by their ability to produce $\mathrm{CO}_{2}$ from glucose and gluconate. Phenotypic characteristics of all yeast isolates was determining by their morphology, spore formation, assimilation and fermentation of different carbon sources (3) and yeast identities were verified using the keys of Yeast $(3,14)$.

\section{Molecular identification of microorganisms}

Representatives of each species of microorganisms identified by traditional methods were selected $(\sqrt{ } \mathrm{n}=\ln \mid$ for numbers of microorganisms identified of each species) for sequencing. DNA from pure cultures of the bacteria and yeasts isolated was extracted according to the method described by Wang et al. (29) and Makimura et al. (17), respectively.
Sequencing of portions of the $16 \mathrm{~S}$ rRNA gene and Iternal Tanscribed Spacer region (ITS) was used for identification of representative bacteria and yeast isolates to species level. The primers 27f (5'-AGAGTTTGATCCTGGCTCAG-3') and 1512r (5'- CGGCTACCTTGTTACGACT - 3') were used to amplify $16 \mathrm{~S}$ rRNA gene while the primers ITS1 (5'TCCGTAGGTGAACCTGCGG-3') and ITS4 (5'-TCCTCCGC TTATTGATATGC-3') were used to amplify ITS region. PCR was performed according to Wang et al. (29) (bacteria) and Naumova et al. (21) (yeast). The amplicons were analysed by electrophoresis on agarose gels at $60-65 \mathrm{~V}$. The sequencing of portions of the $16 \mathrm{~S}$ rRNA gene and ITS region was accomplished by the (Applied Biosystems Company, Foster City, CA, USA). GenBank searches (http://www.ncbi.nlm.nih. gov/BLAST/) were performed to determine the closest known relatives of the partial ribosomal DNA sequences obtained.

\section{Analysis by Scanning Electron Microscopy (SEM)}

Brazilian kefir grains were sliced for Scanning Electron Microscopy (SEM) (18). Samples were collected from the outer and inner parts of the grains. The grains were fixed (Karnovisk's fixative solution) at pH 7.2 for $24 \mathrm{~h}$. The samples were then transferred to $30 \%$ glycerol for $30 \mathrm{~min}$ and immersed in liquid nitrogen for subsequent fracture in the metal surface. Then, grains were post-fixed in $10 \mathrm{~g} / \mathrm{l}$ osmium tetroxide in phosphate buffer for $1 \mathrm{~h}$ at $25^{\circ} \mathrm{C}$ and dehydrated in acetone: 15 , 30, 50 and $70 \%$, three times. After dehydrating, samples were critical-point dried and coated with gold using a Bal-tec SDC 050(Capovani Brothers Inc. Scotia, NY, USA). The preparations were observed using a scanning electron microscope (LEO EVO 040) (A Carl Zeiss SMT AG Company, Germany).

\section{Chemical analysis}

At 0 and $24 \mathrm{~h}$, the kefir beverage samples were characterized in relation to total titratable acidity and $\mathrm{pH}$, protein, fat and vitamin $\mathrm{C}$ (ascorbic acid) content and dry 
matter according to the AOAC methodology (1). Calcium was determined by atomic absorption spectrophotometry using a Varian (Model SpectrAA 100/200) spectrophotometer equipped with an air-acetylene flame. Ethanol, organic acids (acetic acid and lactic acid) and lactose were obtained from sample extracts every $6 \mathrm{~h}$ and analysed according Schwan et al. (26) and Duarte et al. (7). All samples were examined in triplicate.

\section{RESULTS AND DISCUSSION}

\section{Microbial enumeration}

Descriptions of yeast and bacteria present in different batches of milk kefir grains have been reported by different authors $(27,30,31)$. However, these studies were restricted to the grains, and none of them analysed the beverage. Using conventional culture techniques, we have monitored the development of bacterial and fungal communities during 24h fermentation of Brazilian kefir beverage. Previous results showed that two groups of microorganisms co-exist in milk kefir grains: lactic acid bacteria and yeast $(10,23)$. In order to establish the different species of bacteria and yeast present during fermentation, a representative number of isolates from each culture medium were identified (Table 1). Lactic acid bacteria was the most frequently found microorganism group, showing an initial population of around $3.51 \log _{10}$ c.f.u. $/ \mathrm{ml}$ that reached $12.41 \log _{10}$ c.f.u./ml. Acidification of the substratum was mainly stimulated by the presence of lactic acid bacteria (9). Acetobacter showed also growth, ranging from $5.92 \log _{10}$ c.f.u./ml to $7.72 \log _{10}$ c.f.u./ml. In general, lactic acid bacteria were more numerous than yeast and acetic acid bacteria in milk kefir grains, although fermentation conditions can affect this pattern (10).

Table 1. Microbial enumeration ( $\log _{10}$ c.f.u./ml) during fermentation of Brazilian kefir grains.

\begin{tabular}{lcccccccc}
\hline & \multicolumn{10}{c}{ Fermentation (h) } \\
\hline $\begin{array}{l}\text { Culture } \\
\text { Medium/Microorganism group }\end{array}$ & SWI & $\mathbf{0}$ & $\mathbf{6}$ & $\mathbf{1 2}$ & $\mathbf{1 8}$ & $\mathbf{2 4}$ & Min & Max \\
\hline $\begin{array}{l}\text { Edwards modified/Lactic acid } \\
\text { bacteria }\end{array}$ & n.d & $3.51 \pm 0.01$ & $4.11 \pm 0.03$ & $4.42 \pm 0.08$ & $4.61 \pm 0.07$ & $7.54 \pm 0.01$ & $3.51 \pm 0.01$ & $7.54 \pm 0.01$ \\
Nutrient Agar/Lactic acid bacteria & n.d & $5.81 \pm 0.01$ & $6.51 \pm 0.01$ & $6.91 \pm 0.02$ & $7.12 \pm 0.02$ & $7.34 \pm 0.04$ & $5.81 \pm 0.01$ & $7.34 \pm 0.04$ \\
LUSM/Lactic acid bacteria & n.d & $6.72 \pm 0.01$ & $6.04 \pm 0.02$ & $7.51 \pm 0.01$ & $7.62 \pm 0.01$ & $10.41 \pm 0.02$ & $6.72 \pm 0.01$ & $10.41 \pm 0.02$ \\
MRS/Lactic acid bacteria & n.d & $6.31 \pm 0.02$ & $6.14 \pm 0.01$ & $6.52 \pm 0.01$ & $7.43 \pm 0.01$ & $12.41 \pm 0.03$ & $5.31 \pm 0.04$ & $12.41 \pm 0.03$ \\
M17/Lactic acid bacteria & n.d & $6.13 \pm 0.01$ & $6.21 \pm 0.02$ & $6.42 \pm 0.01$ & $6.63 \pm 0.01$ & $7.21 \pm 0.02$ & $6.13 \pm 0.01$ & $7.21 \pm 0.02$ \\
135 medium/Acetic acid bacteria & n.d & $5.92 \pm 0.01$ & $6.13 \pm 0.01$ & $6.63 \pm 0.01$ & $7.33 \pm 0.01$ & $7.72 \pm 0.01$ & $5.92 \pm 0.01$ & $7.72 \pm 0.01$ \\
YEPG/Yeast & n.d & $6.21 \pm 0.01$ & $6.72 \pm 0.01$ & $7.32 \pm 0.01$ & $7.43 \pm 0.01$ & $8.11 \pm 0.03$ & $6.21 \pm 0.01$ & $8.11 \pm 0.03$ \\
\hline
\end{tabular}

$\overline{\text { SWI }}=$ Substrate without inoculum, n.d. $=$ not detected. Data are average values of triplicate \pm standard deviation.

\section{Identification of microbial isolates}

Yeasts and bacteria were identified by phenotypic methods (Table 2). Representatives of each species of microorganisms identified by phenotypic methods were selected for sequencing of the ITS region and 16S rRNA gene. Table 2 shows the accession number and the percentage of similarity between the sequences of the isolates from kefir beverage and the reference sequences from GenBank. Isolates showed $97 \%$ or higher similarities with respect to the sequences available in the NCBI database.

A total of 359 isolates were obtained from Brazilian kefir beverage (Table 2). Among the isolates, 249 were bacteria and 110 were yeast. During the fermentative process, the predominant microorganisms identified were lactic acid bacteria $(60.5 \%)$, followed by yeast $(30.6 \%)$ and acetic acid bacteria $(8.9 \%)$. The culture-dependent approach indicated that 
Lactobacillus paracasei represented the largest and most commonly identified LAB isolates, with 89 of a total of 249 isolates, followed by Lactobacillus parabuchneri (41 isolates), Lactobacillus casei (32 isolates), Lactobacillus kefiri (31 isolates) and Lactococcus lactis (24 isolates)

Our data indicated that the Brazilian kefir beverage contained a diverse spectrum LAB group including Lactobacillus and Lactococcus. Lactobacillus kefiri is another important bacterium found during kefir fermentation. There are reports on the presence of Lactobacillus kefiri as a prevailing member of the lactic acid microbiota in milk Kefir $(8,10,16)$. In our study, Lactobacillus kefiri fixed on the grain surface might be easily freed from kefir grains into the substrate of milk, thus resulting in the increased cell counts. Lactobacillus kefiri is also important for production of kefiran polymer present in the kefir grains structure (6). Kefiran has frequently been claimed to be effective against a variety of complaints and diseases. Several studies have investigated the antitumor activity (6), antibacterial and antifungal activities (25). Lactococcus lactis (24 isolates) was also identified in Brazilian kefir beverage. Previous studies showed that a variety of different species of Lactobacillus and Lactococcus have been isolated and identified in milk kefir grains from around the world $(10,16)$. The acetic acid species, Acetobacter lovaniensis, was also identified (32 isolates). Acetobacter lovaniensis species belongs to the Acetobacter pasteurianus group. The species Acetobacter pasteurianus consists of five subspecies, and Acetobacter pasteurianus subsp. lovaniensis has been also described in fermented food from Indonesia and the Philippines (16) and sugary Brazilian kefir (16).

Table 2. Identification of representative bacterial and yeast isolates by sequencing of portions of the 16S rRNA and ITS, respectively.

\begin{tabular}{|c|c|c|c|c|c|c|c|c|c|c|}
\hline \multirow{2}{*}{ Isolates species } & \multirow{2}{*}{ Identity (\%) } & \multirow{2}{*}{$E$ value } & \multirow{2}{*}{ GenBank accession $n^{\circ}$} & \multirow{2}{*}{$\begin{array}{c}\text { Identified number/ } \\
\text { total isolates }\end{array}$} & \multicolumn{6}{|c|}{ Fermentation time (h) } \\
\hline & & & & & SWI & 0 & 6 & 12 & 18 & 24 \\
\hline \multicolumn{11}{|l|}{ Bacteria } \\
\hline Lactobacillus kefiri & 99 & 0.0 & AB362680.1 & $31 / 249$ & n.d. & (2) & (15) & (2) & $(3)$ & (9) \\
\hline Lactobacillus parabuchneri & 99 & 0.0 & AB368914.1 & $41 / 249$ & n.d. & (7) & (2) & (10) & (8) & (14) \\
\hline Lactobacillus paracasei & 98 & 0.0 & AB368902.1 & $89 / 249$ & n.d. & (20) & (9) & (18) & (12) & (30) \\
\hline Lactobacillus casei & 99 & 0.0 & EU626005.1 & $32 / 249$ & n.d. & (1) & (1) & (4) & $(8)$ & (18) \\
\hline Lactococcus lactis & 99 & 0.0 & EU194346.1 & $24 / 249$ & n.d. & (2) & (1) & $(2)$ & (7) & (12) \\
\hline Acetobacter lovaniensis & 98 & 0.0 & AB308060.1 & $32 / 249$ & n.d. & (3) & (3) & (6) & (8) & $(12)$ \\
\hline Total & & & & & & & & & & 249 \\
\hline \multicolumn{11}{|l|}{ Yeast } \\
\hline Kluyveromyces lactis & 99 & 0.0 & AJ229069.1 & $31 / 110$ & n.d. & (4) & $(5)$ & $(5)$ & $(6)$ & $(11)$ \\
\hline Kazachstania aerobia & 99 & 0.0 & AY582126.1 & $23 / 110$ & n.d. & (3) & (3) & $(4)$ & (4) & (9) \\
\hline Lachancea meyersii & 99 & 0.0 & AY645661.1 & $15 / 110$ & n.d. & n.d & $(2)$ & $(3)$ & (2) & (8) \\
\hline Saccharomyces cerevisiae & 97 & 0.0 & EU019225.1 & $41 / 110$ & n.d. & (4) & (9) & $(4)$ & (4) & $(20)$ \\
\hline Total & & & & & & & & & & 110 \\
\hline
\end{tabular}

SWI = Substrate without inoculum; n.d. = not detected; $($ ) = numbers of microrganism identified.

The lactose-fermenting yeast, Kluyveromyces lactis, was found in the Brazilian kefir beverage together with non-lactosefermenting yeast: Saccharomyces cerevisiae, Lachancea meyersii and Kazachstania aerobia (Table 2). The yeast isolates of Brazilian kefir was dominated by lactose-negative strains. Among them, Saccharomyces cerevisiae predominated (41isolates), followed by Kazachstania aerobia (23 isolates) and Lachancea meyersii (15 isolates). Saccharomyces cerevisiae represented the largest and most commonly identified yeast isolates. This species, which exhibits strong fermentative metabolism and tolerance to ethanol, is known to be superior to non-Saccharomyces yeast in the process of 
alcohol fermentation, regarding spontaneous fermented sugar cane (26). The presence of Saccharomyces cerevisiae contributes to the enhancement of the sensory quality of the kefir beverage, promoting a strong and typically yeasty aroma, as well as its refreshing, pungent taste (16). This yeast also reduces the concentration of lactic acid, removes the hydrogen peroxide and produces compounds that stimulate the growth of other bacteria, thus increasing the production of kefiran exopolysaccharides (6). It is worth noting that the yeast species, Kazachstania aerobia and Lachancea meyersii whose presence in milk kefir has not been reported previously, was detected in this study. Its presence in Brazilian kefir beverage could be connected with the assimilation of some acids produced by lactic acid bacteria.

\section{Scanning electron microscopy of milk Brazilian kefir grains}

As described previously by some authors (10, 23), a complex and tightly packed biofilm could be observed around the grains, while the interior was comprised mainly of unstructured material. Figure 1 and 2 show the association of the kefir microbiota through scanning electron microscopy
(SEM). The Brazilian kefir grains showed a smooth surface (Figure 1A) and its outer portion was covered by an agglomerate of microorganisms (Figure 1B,C and D). The microbiota in the outer portion of the grain was dominated by bacilli (Short and curved long) cells growing in association with lemon-shaped yeast cells (Figure 1B,C and D). The microbial cells on the inner portion were less than that on the outer portion (Figure 2). Fibrillar material (probably the polysaccharide kefiran) was observed on the outer portion, as well as in the inner portion of the grains (Figure $1 \mathrm{C}$ and $2 \mathrm{~B}$ ). Similar results for Turkish kefir grains (10) and sugary kefir grains (16) were found.

Based on the results from plating, Lactococcus lactis species were identified as member of the lactic acid bacteria population (Table 2). However cocci bacteria could not be seen on the SEM graph in our study, thus suggesting the weak adherence of these two species on Brazilian kefir grains. This weak adherence may have resulted in the bacteria falling into the milk substrates, a possibility that is in agreement with the results reported by Guzel-Seydim et al. (10) for Turkey kefir grains and Magalhães et. al. (16) for sugary Brazilian kefir.
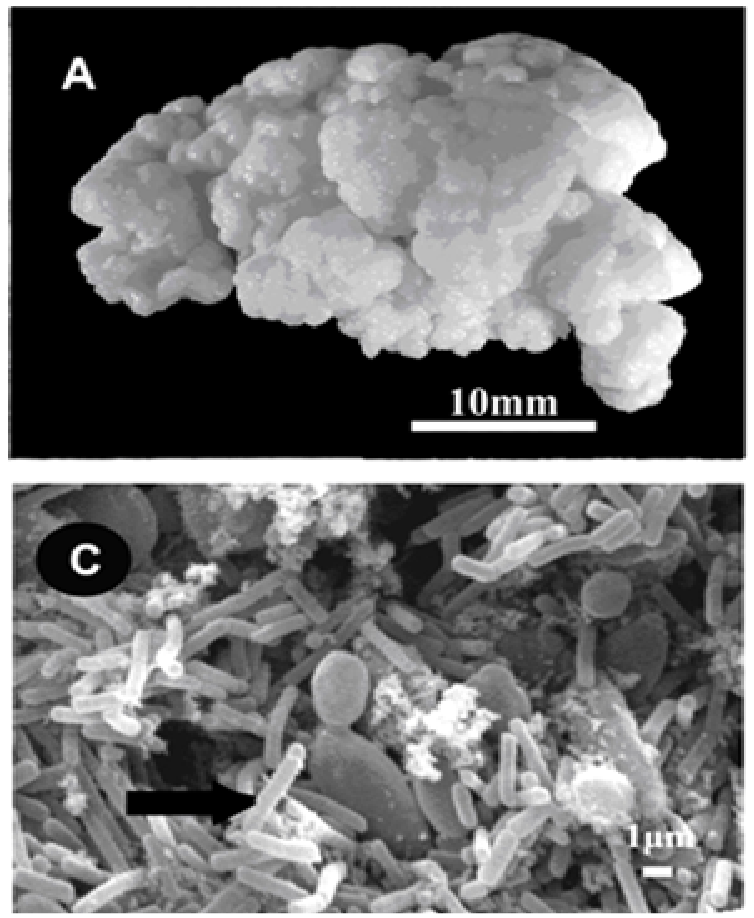
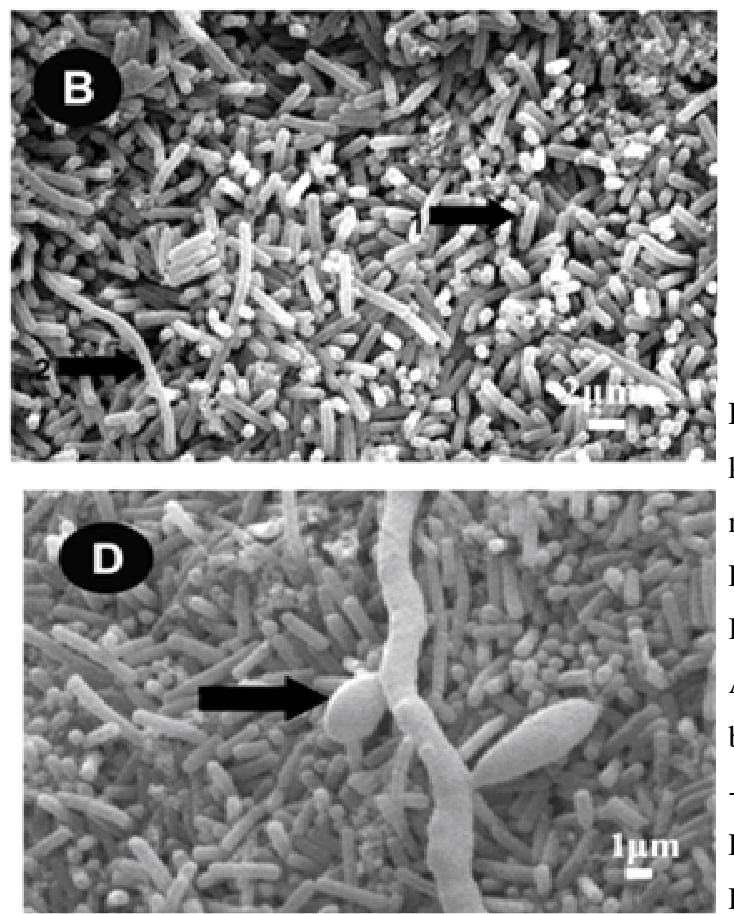

Figure 1. A - Brazilian kefir grain viewed with the naked eye. B,C,D External surface of Brazilian kefir grain. Arrow 1Fig. 1B - Short bacteria. Arrow 2 Fig. 1B Long bacteria. Arrows Fig. 1C - Bacteria. Arrows Fig. 1D - Yeasts. 

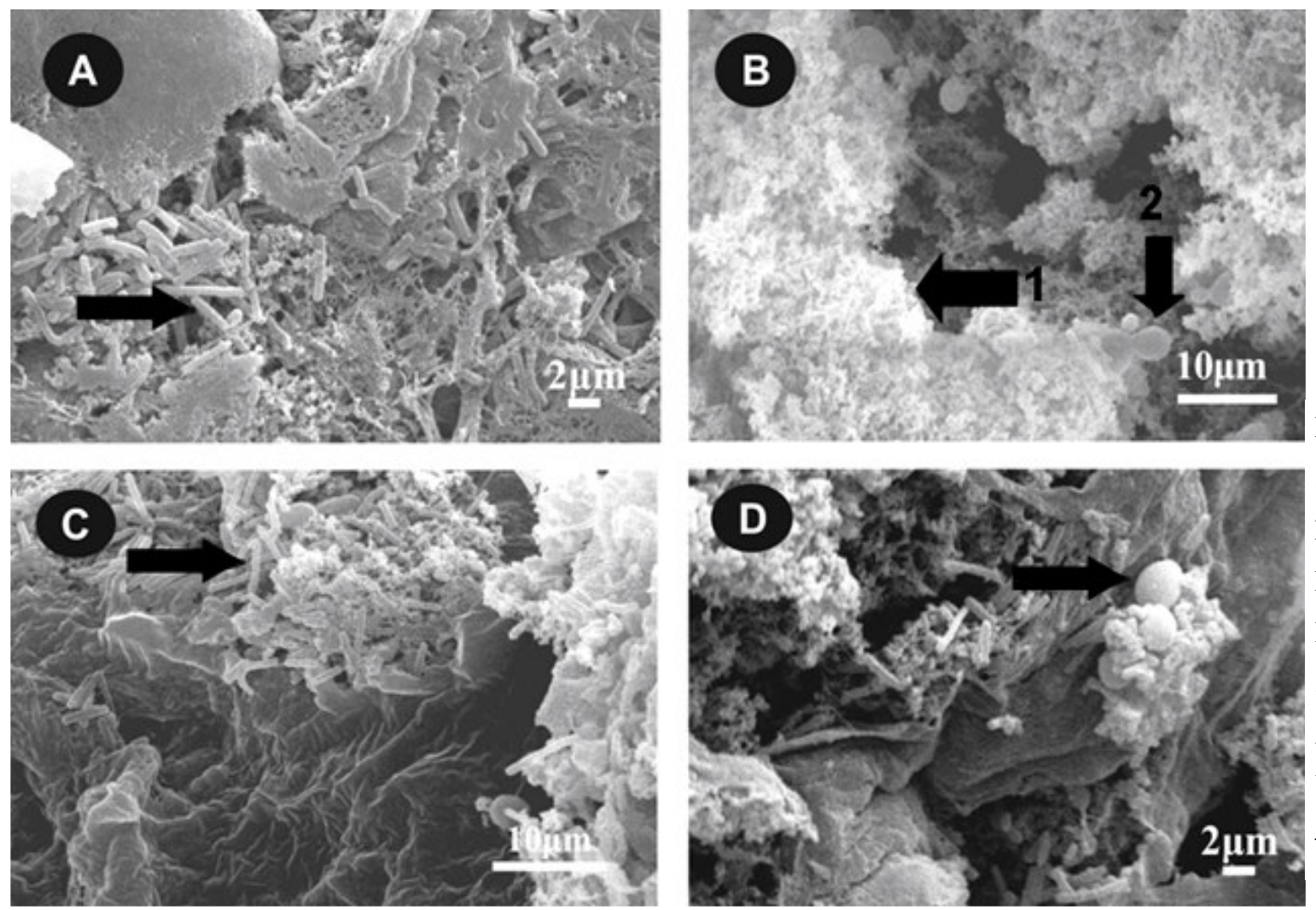

Figure 2. Internal surface of Brazilian kefir grain. Arrows Fig. $3 \mathrm{~A}$ and $3 \mathrm{C}-$ Bacteria. Arrow 1 Fig. 3B - Polysaccharide. Arrow 2 Fig. 3B Yeasts. Arrow Fig. 3D - Yeasts.

\section{Chemical characterization of fermented kefir beverage}

Table 3 shows the $\mathrm{pH}$ and total titratable acidity (TTA) values over a $24 \mathrm{~h}$ fermentation period. The mean $\mathrm{pH}$ and TTA values of the pasteurized whole milk prior to inoculation with kefirr grains were 6.61 and $26^{\circ} \mathrm{D}$, respectively. The $\mathrm{pH}$ decreased to 4.42 and the TTA increased to $93^{\circ} \mathrm{D}$ during the $24 \mathrm{~h}$ fermentation of milk by Brazilian kefir grains. The main reason for $\mathrm{pH}$ decrease and TTA increase is the production of certain organic acids, ethanol, $\mathrm{CO}_{2}$, and other volatile compounds by the microbial population in grains and kefir beverage $(2,9)$. Calcium content was not modified during the fermentation and Vitamin $\mathrm{C}$ was not found (Table 3). The content of fat decreased, due to the lipases production by the microorganisms present in kefir (13). The protein content increased, due to the increase of the microbial biomass; however the dry matter contents of kefir grains remained constant in the final fermentation process (Table 3 ).
Table 3. Values of total titratable acidity, $\mathrm{pH}$, proteins, fat, vitamin $\mathrm{C}$, Calcium in Brazilian kefir beverage and dry matter in Brazilian kefir grains.

\begin{tabular}{|c|c|c|}
\hline \multirow[t]{2}{*}{ Chemical characteristics } & \multicolumn{2}{|c|}{ Fermentation time (h) } \\
\hline & $\mathbf{0}$ & 24 \\
\hline \multicolumn{3}{|l|}{ Beverage } \\
\hline Total titratable acidity (TTA) $\left({ }^{\circ} \mathrm{D}\right)$ & $26 \pm 1$ & $93 \pm 1$ \\
\hline $\mathrm{pH}$ & $6.61 \pm 0.02$ & $4.42 \pm 0.01$ \\
\hline Proteins $(\%)$ & $2.12 \pm 0.02$ & $3.91 \pm 0.02$ \\
\hline Fat $(\%)$ & $3.63 \pm 0.03$ & $2.34 \pm 0.01$ \\
\hline Vitamin C (\%) & n.d. & n.d. \\
\hline Calcium $(\mathrm{Ca})(\%)$ & $0.21 \pm 0.01$ & $0.22 \pm 0.01$ \\
\hline \multicolumn{3}{|l|}{ Grains } \\
\hline Dry matter $(\%)$ & $9.84 \pm 0.02$ & $9.62 \pm 0.03$ \\
\hline
\end{tabular}

n.d. = not detected

Data are average values of triplicate \pm standard deviation.

High performance liquid chromatography (HPLC) was used to analyze organic acids, ethanol e sugars in the kefir beverages produced. Figure 3 shows the concentration of 
sugars, organic acids and ethanol obtained through milk fermentation. Lactose, lactic acid, acetic acid and ethanol were quantified by HPLC. Organic acids may occur in dairy products as a result of hydrolysis of butterfat (fatty acids), biochemical metabolic processes, or bacterial metabolism (9).

The lactose consumption was observed after $24 \mathrm{~h}$ of milk fermentation (Figure 3). Lactose is readily degraded to galactose and glucose by some strains of Streptococcus and Kluyveromyces. Similar results were reported by Irigoyen et al. (13) during milk fermentation with $5 \%$ inoculum of kefir grains. According to Irigoyen et al. (13), the percentage of kefir grains inoculated in the substrate, as well as the cultivation method employed affects the lactose consumption.

In the present work, the lactic acid content increased during the $24 \mathrm{~h}$ of the fermentation process in Brazilian kefir beverage, reaching maximum value of $17.4 \mathrm{mg} / \mathrm{ml}$. This result is of great importance, since lactic acid acid provides pleasant taste and inhibits the development of undesirable or pathogenic microorganisms, due to the substrate acidity increase (16).
Acetic acid was also formed during the fermentation process of Brazilian kefir beverage (Figure 3), probably by heterolactic bacteria (16) which were identified in the present work (Table 2). Similar to lactic acid, accumulation of acetic acid turns the beverage more acidic and inhibitory for pathogens microorganisms (16).

Ethanol concentration increased during the kefir beverage fermentation process (Figure 3); reaching maximum concentration of $0.5 \mathrm{mg} / \mathrm{ml}$. Saccharomyces cerevisiae identified in kefir beverages in the present work is primarily responsible for the alcohol production. However, some Lactobacillus strains also have the ability to produce ethanol, since they possess alcohol-dehydrogenase activity, an enzyme able to convert acetaldehyde to ethanol (4). The content of alcohol should be enough to give kefir the flavour of a light alcoholic beverage that is typical of traditional (ancient) kefir of the Caucasus and the yeast aroma ensures the specificity of this type of fermented beverage (4).

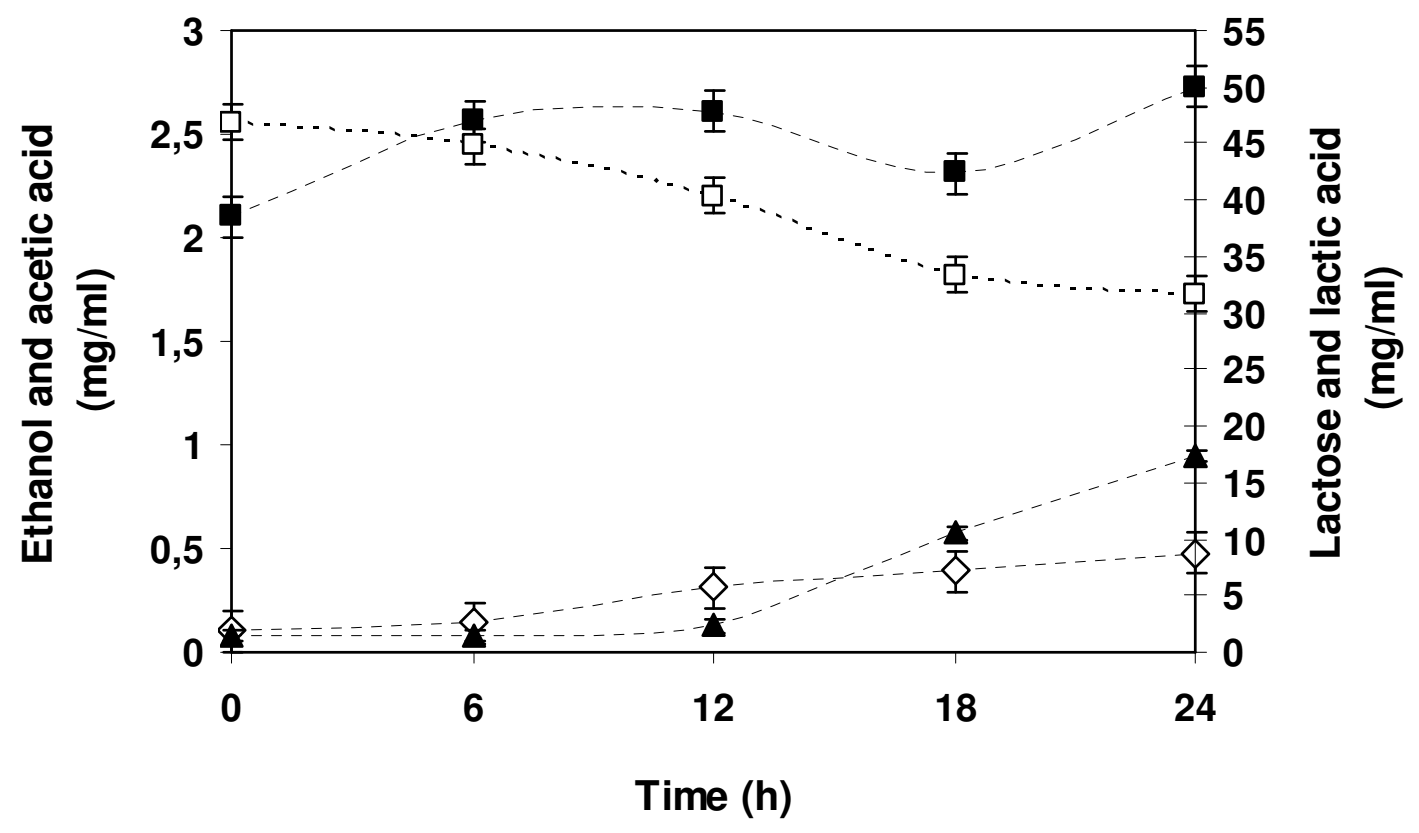

Figure 3. Consumption of lactose $(\square)$ and production of ethanol $(\diamond)$, acetic acid ( $\boldsymbol{\square})$ and lactic acid ( $\boldsymbol{\Delta})$ during fermentation of the milk by Brazilian kefir grains at $25^{\circ} \mathrm{C}$. Bars indicated standard deviation. 


\section{CONCLUSIONS}

Three distinct microbial populations were identified during the fermentation of Brazilian kefir beverage: lactic acid bacteria were the predominant, followed by the yeasts and Gram-negative bacteria from the Acetobacter genus. Lactobacillus paracasei was the most abundant bacterium, while Saccharomyces cerevisiae was the predominant yeast strain. The distinct microorganism groups identified in this beverage performed three different kinds of fermentations, including lactic, alcoholic and acetic fermentations. The increase in lactic bacteria population caused an increase in the lactic acid concentration in the beverage, whereas the increase in yeast population favored the ethanol formation. To the best of our knowledge, this is the first study evaluating chemical and microbiological composition of Brazilian kefir beverage. Interestingly, two microbial species that had not been described as belonging to the microbiota of milk kefir were found in Brazilian kefir: Lachancea meyersii and Kazachstania aerobia. The present study contributes for a better knowledge of the microbiological and chemical constitution of the kefir beverage consumed in Brazil, which have not been elucidated up till now. Future work involving nutritional and therapeutic benefits will improve the characterization of Brazilian kefir.

\section{ACKNOWLEDGEMENTS}

The authors acknowledge Coordenação de Aperfeiçoamento de Pessoal de Nível Superior (CAPES) for scholarshipsand and CAARG - Cooperativa Agrícola Alto Rio Grande Ltda. (Lavras/MG, Brazil) for the milk supply.

\section{REFERENCES}

1. Association of Official Analytical Chemist. (2000). Official Methods of Analysis of the Association of Official Analytical Chemist. $17^{\text {th }} \mathrm{ed}$. Washington.

2. Athanasiadis, I.; Paraskevopoulou, A.; Blekas, G.; Kiosseoglou, V. (2004). Development of a novel whey beverage by fermentation with kefir granules. Effect of various treatments. Biotech. Progr. 20 (4), 10911095.

3. Barnett, J.A.; Payne, R.W.; \& Yarrow, D. (2000). Yeast. Characteristic and Identification. $3^{\text {rd }}$ ed. Cambridge, UK: Cambridge Univ. Press. p. 1150.

4. Beshkova, D.M.; Simova, E.D.; Frengova, G.I.; Simov, Z.I.; Dimitrov, Z.H.P. (2003). Production of volatile aroma compounds by kefir stater cultures. Int. Dairy J., 13 (7), 529-535.

5. Chaves, A.C.S.D.; Ruas-Madiedo, P.; Starrenburg, M.; Hugenholtz, J.; Lerayer, A.L.S. (2003). Impact of engineered Streptococcus thermophilus trains overexpressing glyA gene on folic acid and acetaldehyde production in fermented Milk. Braz. J. Microbiol. 34, 1720.

6. Cheirsilp, B.; Shoji, H.; Shimizu, H.; Shioya, S. (2003). Interactions between Lactobacillus kefiranofaciens and Saccharomyces cerevisiae in mixed culture for kefiran production. J. Biosci. Bioeng., 96 (3), 279-284.

7. Duarte, W.F.; Dias, D.R.; Pereira, G.V.M.; Gervasio, I.M.; Schwan, R.F. (2008) Indigenous and inoculated yeast fermentation of gabiroba (Campomanesia pubescens) pulp for fruit wine production. J. Ind. Microbiol. Biotechnol. 36, 557-569.

8. Garrote, G.L.; Abraham, A.G.; de Antoni, G.L. (1997). Preservation of kefir grains, a comparative study. Lebensm.-Wiss. U.-Technol., 30 (1), $77-84$.

9. Güzel-Seydim, Z.B.; Seydim, A.C.; Greene, A.K.; \& Bodine, A.B. (2000). Determination of organic acids and volatile flavor substances in kefir during fermentation. J. Food Compos. Anal., 13 (1), 35-43.

10. Güzel-Seydim, Z.; Wyffels, J.T.; Seydim, A.C.; \& Greene, A.K. (2005). Turkish kefir and kefir grains: microbial enumeration and electron microscobic observation. Int. J. Dairy Technol., 58 (1), 25-29.

11. Hammes, W.P.; Hertel, C. (2003). The genera Lactobacillus and Carnobacterium. In: Dworkin, M. (Eds.). The prokaryotes. New York: Springer-Verlang. New York, USA, p. 1535-1594.

12. Holt, J.G.; Krieg, N.R.; Sneath, P.H.A.; Staley, J.T.; Williams, S.T. (1994). Bergey's manual of determinative bacteriology. $9^{\text {th }}$ ed. Baltimore: Williams \& Wilkins, Baltimore, USA.

13. Irigoyen, A.; Arana, I.; Castiella, M.; Torre, P.; Ibáñez, F.C. (2005). Microbiological, physicochemical, and sensory characteristics of kefir during storage. Food Chem., 90 (4), 613-620.

14. Kurtzman, C.P.; Boekhout, T.; Robert, V.; Fell, W.J.; Deak, T. (2003). Methods to identify yeasts. In: V. Robert (Ed.). Yeasts in food: beneficial and detrimental aspects. Hamburg, Germany: B. Beh's Verlag GmbH., p. 69-117.

15. Lee, M.Y.; Ahn, K.S.; Kwon, O.K.; Kim, M.J.; Kim, M.K.; Lee, I.Y.; Oh, S.R.; Lee, H.K. (2007). Anti-inflammatory and anti-allergic effects of kefir in a mouse asthma model. Immunobiol., 212 (8), 647-654.

16. Magalhães, K.T.; Pereira, G.V.M.; Dias, D.R.; Schwan, R.F.; (2010). Microbial communities and chemical changes during fermentation of 
sugary Brazilian kefir. World J. Microbiol. Biotechnol., 33, 1-10.

17. Makimura, K.; Tamura, Y.; Mochizuki, T.; Hasegawa, A.; Tajiri, Y.; Hanazawa, R.; Uchida, K.; Saito, H.; Yamaguchi, H. (1999). Phylogenetic classification and species identification of dermatophyte strains based on DNA sequences of nuclear ribosomal internal transcribed spacer 1 regions. J.Clin. Microbiol., 37 (4), 920-924.

18. Marques, S.C.; Rezende, J.G.O.S.; Alves, L.A.F.; Silva, B.C.; Alves, E.; Abreu, L.R.; Piccoli, R.H. (2007). Formation of biofilms by Staphylococcus aureus on stainless steel and glass surfaces and its resistance to some selected chemical sanitizers. Braz. J. Microbiol.,.38 (3), 538-543 .

19. Medrano, M.; Pérez, P.F.; Abraham, A.G. (2008). Kefiran antagonizes cytopathic effects of Bacillus cereus extracellular factors. Int. J. Food Microbiol., 122 (1), 1-7.

20. Moreira, S.R.; Schwan, R.F.; Carvalho, E.P.; Wheals, A.E. (2001). Isolation and identification of yeasts and filamentous fungi from yoghurts in Brazil. Braz. J. Microbio.l, 32 (2), 117-122.

21. Naumova, E.S.; Ivannikova, Yu.V.; Naumov, G.I. (2004). Genetic differentiation of the sherry yeasts Saccharomyces cerevisiae. Appl. Biochem. Microbiol., 41 (6), 578-582.

22. Otles, S.; Cagindi, O. (2003). Kefir: a probiotic dairy-composition, nutritional and therapeutic aspects. Pak. J. Nutr., 2 (1), 54-59.

23. Rea, M.C.; Lennartsson, T.; Dilon, P.; Drinan, F.D.; Reville, W.J.; Heapes, M.; Cogan, T.M. (1996). Irish kefir like grains: their structure, microbial composition and fermentation kinetics. J. Appl. Microbiol., 81 (1), 83-94.
24. Rimada, P.S.; Abraham, A.G. (2006). Kefiran improves rheological properties of glucono- $\delta$-lactone induced skim milk gels. Int. Dairy J., 16 (1), 33-39.

25. Rodrigues, K.L.; Caputo, L.R.G.; Carvalho, J.C.T.; Evangelista, J.; Schneedorf, J.M. (2005). Antimicrobial and healing activity of kefir and kefiran extract. Int. J. Antimicrob. Ag., 25 (5), 404-408.

26. Schwan, R.F.; Mendonça, A.T.; Silva Jr, J.J.; Rodrigues, V.; Wheals, A.E. (2001). Microbiology and physiology of cachaça (aguardente) fermentations. Anton. Leeuw. Int. J. G., 79, 89-96.

27. Simova, E.; Beshkova, D.; Angelov, A.; Hristozova, Ts.; Frengova, G.; Spasov, Z. (2002). Lactic acid bacteria and yeasts in kefir grains and kefir made from them. J. Ind. Microbiol. Biotechnol., 28 (1), 1-6.

28. Vinderola, C.G.; Duarte, J.; Thangavel, D.; Perdigón, G.; Farnworth, E.; Matar, C. (2005). Immunomodulating capacity of kefir. J. Dairy Res., 72 (2), 195-202.

29. Wang, X.; Haruta, S.; Wang, P.; Ishii, M.; Igarashi, Y.; Cui, Z. (2006). Diversity stable enrichment culture which is useful for silage inoculant and its succession in alfalfa silage. FEMS Microbiol. Ecol., 57 (1), 106115 .

30. Witthuhn, R.C.; Schoeman, T.; Britz, T.J. (2005). Characterisation of the microbial population at different stages of kefir production and kefir grain mass cultivation. Int. Dairy J., 15 (4), 383-389.

31. Yüksekdag, Z.N.; Beyatli, Y.; Aslim, B. (2004). Determination of some characteristics coccoid forms of lactic acid bacteria isolated from Turkish kefirs with natural probiotic. Lebensm.-Wiss. U.-Technol., 37 (6), 663667. 